\title{
A Kaposvári Egyetem parkjának állatvilága
}

\author{
KOVÁCS-HAJDU KATALIN, NAGYAPÁTI NIKOLETT, BENDE ZSOLT, LENGYEL GÁBOR, \\ SOVÁNY KRISZTINA, GÖRFÖL TAMÁS, VALOVICS SZILVIA és LANSZKI JÓZSEF
}

Kaposvári Egyetem, Természetvédelmi és Környezetgazdálkodási Tanszék, H-7400 Kaposvár, Guba Sándor út 40., e-mail: lanszki.jozsef@ke.hu

Kovács-Hajdu, K., Nagyapáti, N., Bende, Zs., Lengyel, G., SovÁnY, K., Görföl, T., VAlovics Sz. \& LANSZKI, J.: The fauna of the park of University of Kaposvár.

Abstract: We summarised faunistic observations carried out in the park of University of Kaposvár (Kaposvár-Toponár, Somogy county) from the last cca. 15 years. The urban green areas, like the park of our university, are important for many conservation reliant animal species. These green areas provide these species some ecologic services for example: feeding, resting (migrating birds), reproduction and habitats. The checklist of fauna of the university park is based on occasional research performed mainly by students. This record includes 177 invertebrate species (of which 19 are protected), 4 amphibians and 5 reptiles (all protected), 100 birds (of which 9 are strictly protected; 52 nesting species), 31 mammals (of which 15 are protected). Most part of the species detected by us (including common species), are published for the first time in connection with the area studied (Kaposvár-Toponár). Numerous taxa (e.g. near all taxa from invertebrates) are less well explored therefore we encourage further research of the fauna of this university park.

Keywords: fauna, urban habitat, checklist, vertebrate, invertebrate, Somogy county

\section{Bevezetés}

A lakott területek, beleértve a zöldterületek élővilágának feltártsága gyakran elmarad a védett természeti területekétől, annak ellenére, hogy kézenfekvőbb és könnyebb is lenne a bennünket közvetlenül körülvevő környezet élőlényeinek a megfigyelése. A zöldterületek - amilyen a vizsgálatunk tárgyát képező park is - részei a zöldfelületek rendszerének. A zöldterületek céljuk, helyük, használati módjuk és kialakulásuk szerint sokfélék lehetnek: többek között városi díszkertek, üdülő parkok, fasorok, középületek kertjei, lakóházak kertjei, botanikus kertek, temetők. A középületek (pl. oktatási intézmények) kertjei legtöbbször a díszítő célt és az üdülőpark jelleget egyesítik, emellett érdemes szót ejteni például az oktatási funkciójukról is.

A városi zöldfelületek (közöttük a kezelt élöhely foltok, pl. a parkok) ökológiai szerepe sokrétü. Élöhelyként, táplálkozó területként, vonuláskor vonuló területként is szolgálnak számos állatfaj számára. A növényzetük felülete módosítja a besugárzásviszonyokat, miközben a levelek felületén jelentős mennyiségü por kötődik meg, sőt jelentős a $\mathrm{CO}_{2}$ megkötés és az $\mathrm{O}_{2}$ termelés is. A zöldterületek

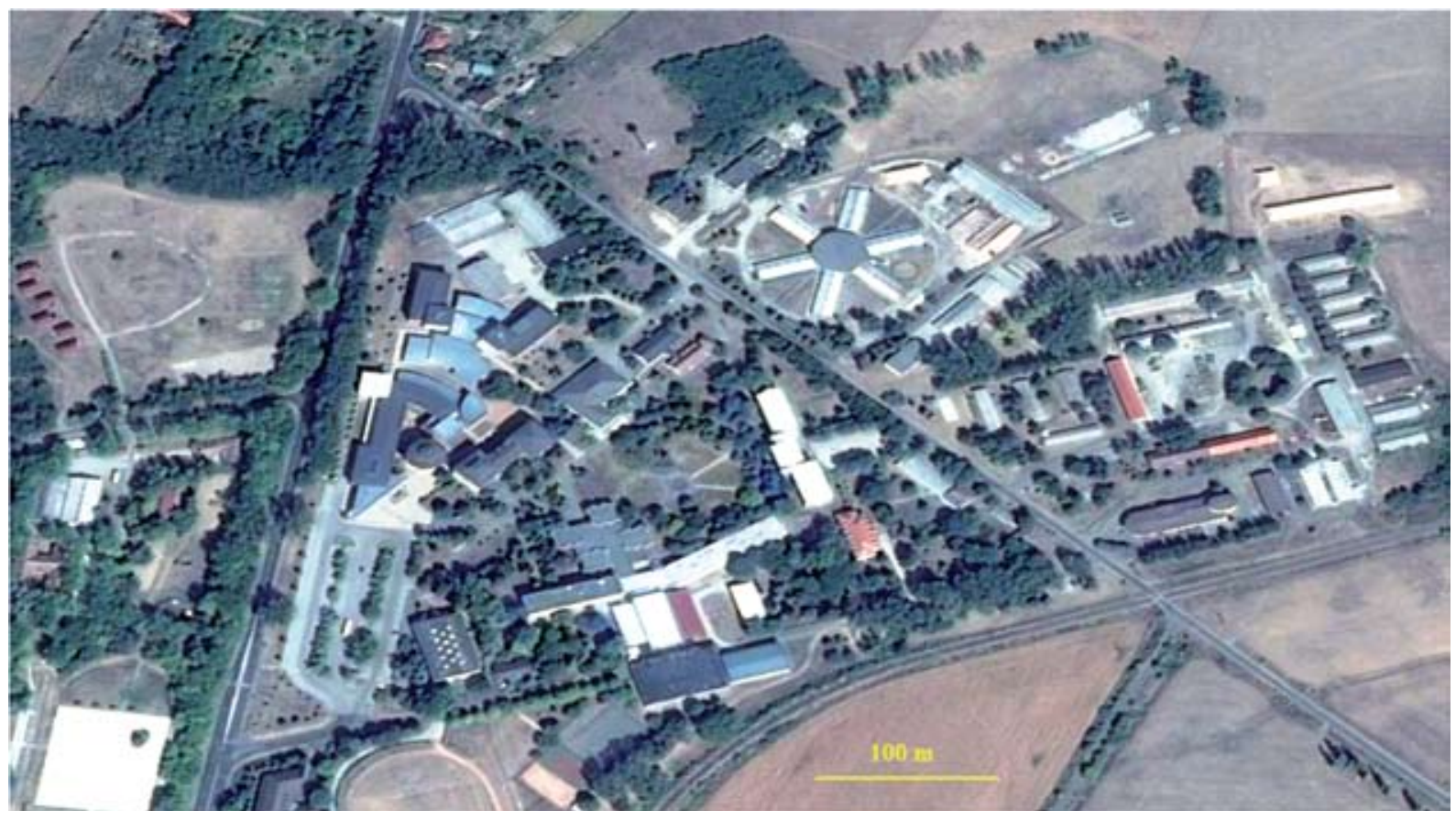

1. ábra: A Kaposvári Egyetem kaposvár-toponári kampuszának látképe (Google Earth) 


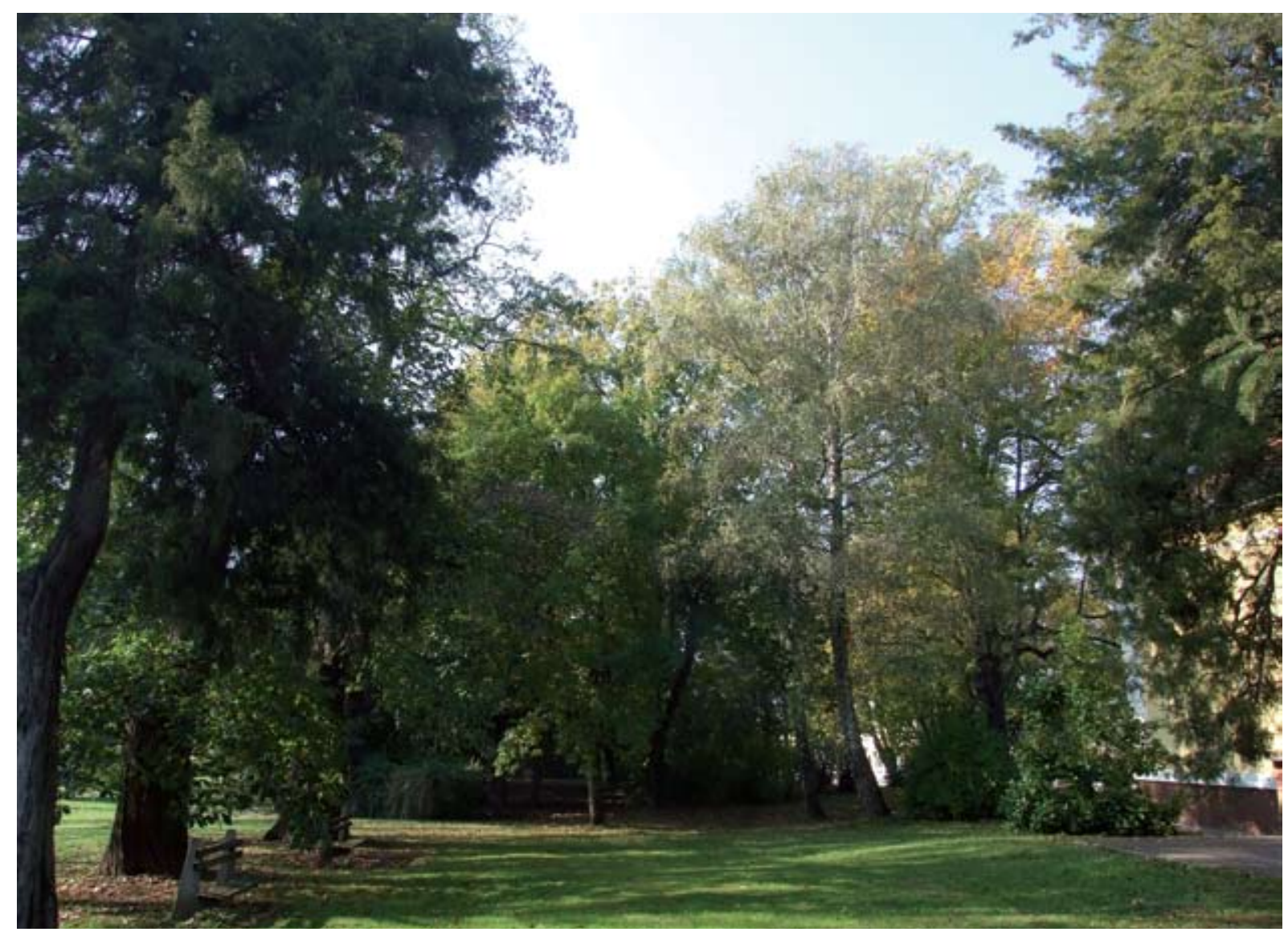

2. ábra: A park részlete (Fotó: Lanszki J.)

zajszürő hatással is rendelkeznek, továbbá csökkentik a szél erősségét. Az intenzív párologtatás révén növelik a levegő páratartalmát, a párolgás pedig hőt von el a környezetböl, ezért a növényzettel fedett területeken hűvösebb a mikroklíma (NAGY 2008). Az elöbb felsorolt környezeti tényezők és a változatos mikroélőhelyek magas száma kedvező a zöldterületek biodiverzitására nézve. Azonban, mivel nem természetes vagy természetközeli élőhelyekröl van szó, a fajösszetétel eltér az eredeti (természetes, őshonos) fajközösségtöl. Azok a fajok találhatók meg itt, melyek képesek voltak alkalmazkodni az emberi környezet folyamatosan változó fizikai és biológiai tényezőihez, valamint az állandó nagymértékű emberi zavaráshoz (HeLTAI és Szöcs 2008).

A közleményünkben szereplő terület a Kaposvári Egyetem Kaposvár-Toponár határában található kampuszának parkja. Célunk az egyetemi parkban az elmúlt kb. 15 évben megfigyelt, kimutatott állatfajok listázása. A megfigyeléseket zömmel az egyetem hallgatói végezték. Tekintettel arra, hogy a terület állatvilágáról eddig csak hiányos ismeretek álltak rendelkezésre, új fajok kimutatását is vártuk Kaposvár-Toponár térségére. Egyúttal igyekszünk rámutatni a feltárás hiányosságaira is, valamint az érdekes és az újabb fajok kimutatásának lehetőségére, ezzel is ösztönözve a jövőbeli célzott felméréseket, illetve alkalmi megfigyeléseket.

\section{Anyag és Módszer}

A Kaposvári Egyetem parkjának növényzetét hazai és idegenhonos fásszárúak, valamint kertészeti dísznövények telepített példányai határozzák meg. Fajösszetételük változatos, azonban térbeli elhelyezkedésük inkább véletlenszerü, vagy praktikussági célokat szolgáló, mintsem a természetes képhez közelítő. A fák korosztályviszonyait tekintve nagy a változatosság - mivel egy folyamatosan változó, fejlődő parkról van szó - azonban általánosan elmondható, hogy a fiatal és középkorú fák túlsúlya jellemző a parkban. Csupán néhány idősebb faegyed fordul elő (egy tulipánfa és néhány szelídgesztenyefa), az odvasodó fák pedig szinte teljesen hiányoznak, amely valószínüleg a parkgondozási hagyományainknak is köszönhetö. Jelenleg különböző típusú madárodúk segítik a madarak fészkelését, denevérodúk pedíg a denevérek megtelepedését.

A növényzettel való borítottság szempontjából 5 alapvető kategóriába sorolhatók a parkban található felületek:

- fatermetű növényzettel borított foltok;

- cserjések;

- fátlan gyepfoltok;

- egyéves, virágos dísznövényekböl álló ágyások;

- növényzet nélküli betonfelületek. 
A legmagasabb szintet a fatermetü növényzettel borított felszín jelenti. Ez esetben figyelmen kívül hagytuk, hogy a fás vegetáció alatt milyen más kategóriába sorolható terület található meg.

A fajokban rendkívül változatos parkban a fás szárú növények között jelentős számban találhatunk őshonos lombhullató fajokat, mint a fekete nyár (Populus nigra), közönséges nyír (Betula pendula), közönséges gyertyán (Carpinus betulus), bükk (Fagus sylvatica), szelídgesztenye (Castanea sativa), kocsányos tölgy (Quercus robur), vadcseresznye (Cerasus avium), korai és hegyi juhar (Acer platanoides, A. pseudoplatanus), kislevelü és ezüsthárs (Tilia cordata, $T$. argentea), vagy a magas kőris (Fraxinus excelsior). Nagy arányban fordulnak elő továbbá olyan idegenhonos lombhullatók, amelyeket gyakran ültetnek parkjainkba: páfrányfenyő (Gingko biloba), amerikai tulipánfa (Liliodendron tulipifera), fekete dió (Juglans nigra), törökmogyoró (Corylus colurna), platán (Platanus $x$ hybrida), vörös tölgy (Quercus rubra), fehér vadgesztenye (Aesculus hippocastanum), szivarfa (Catalpa bignonioides), júdásfa (Cercis siliquastrum). Közülük érdemes különös figyelmet fordítani a hazai körülmények között inváziósan viselkedőkre, mint a zöld juhar (Acer negundo), fehér akác (Robinia pseudo-acacia), bálványfa (Ailanthus altissima), vagy a keskenylevelü ezüstfa (Elaeagnus angustifolia). Az örökzöld fajok közül ezen a vidéken egyik sem fordul elő természetes körülmények között, viszont kedvelt dísznövények, így a Kaposvári Egyetem parkjában is megtalálható a nyitvatermők közül a kolorádói és andalúziai jegenyefenyő, vagy más néven kolbászfenyő (Abies concolor, $A$. pinsapo), a közönséges duglászfenyő (Pseudotsuga menziesii), a közönséges és szúrós lucfenyő, amely ezüstfenyő néven ismert (Picea abies, $P$. pungens), a feketefenyő (Pinus nigra), az óriás mamutfenyő (Sequoiadendron giganteum), az oregoni hamisciprus (Chamaecyparis lawsoniana), valamint a keleti és nyugati tuja (Thuja orientalis, T. occidentalis), a közönséges és nehézszagú boróka (Juniperus communis, J. sabina), a tiszafa (Taxus baccata), továbbá a zárvatermőket képviselő Júlia-borbolya (Berberis julianae) és balkáni babérmeggy (Prunus laurocerasus).

A cserje termetű őshonos fajokat a cserszömörce (Cotinus coggygria), veresgyürü-som (Cornus sanguinea), fekete bodza (Sambucus nigra), közönséges fagyal (Ligustrum vulgare) képviseli, míg az idegenhonos fajok közül jelen van a közönséges mahónia (Mahonia aquifolium), a kerti tamariska (Tamarix tetrandra), a jázmin (Jasminum sp.), a közönséges orgona (Syringa vulgaris), és a ráncoslevelü bangita (Viburnum rhytidophyllum). A cserjék legnagyobb része a fák árnyalásában fejlődik elszórtan, illetve nagyobb, sürün ültetett foltokban, míg kisebb kiterjedésben elöfordulnak olyan bokros területek is, ahol a cserje termetű egyedek jelentik a legmagasabb növényzeti szintet.

A fák és cserjék között, illetve alatt rendszeresen nyírt gyep terül el, túlnyomórészt zavarástürő gyepalkotókkal. A gondozott parkot változatos fajösszetételü egynyári dísznövényekből kialakított ágyások is színesítik.
Az elkülönített kategóriák gyakoriság szerinti eloszlása a következőképp alakul: a legkisebb területarányuk a virágos dísznövényekből álló ágyásoknak és a cserjéseknek van, mindkettő részesedése 1-2\% körüli. Ezt követik a növényzet nélküli betonfelületek (járdák, kisebb terek, parkolók) 4-5\%-nyi kiterjedésükkel, majd a megközelítőleg 30-35\%-ot kitevő gyepterületek. A fennmaradó, és egyben legnagyobb részt, a fatermetü növényzettel borított foltok teszik ki körülbelül $60 \%$-kal. Fontos megjegyezni, hogy az eltérő jellegű növényzeti foltok viszonylag jól elkülönülnek egymástól, többé-kevésbé hiányoznak a szegély-jellegü, átmeneti élőhelyek, amelyek jelenléte további állatfajok megtelepedésének is kedvezhetne.

A gerinctelen fajokat egyrészt megfigyeléssel és hálózással, másrészt kuvik köpetvizsgálatból, illetve a parkban elhelyezett talajcsapdák anyagából mutattuk ki. A madarak, hüllők és kétéltűek adatai alkalmi megfigyelésekből származtak. Az emlősfajokat részben közvetlen megfigyelésekkel, részben élvefogó csapdázással, valamint bagolyköpet-vizsgálatok során azonosítottuk. A megfigyelések alapvetően a müutakkal körülhatárolt háromszög alakú területre vonatkoznak (1. ábra), bár a bagolyfajok egyedei vadászhattak ennél nagyobb területen is.

A Kaposvár-Toponár térségére vonatkozó korábbi előfordulások felderítése érdekében számos szakcikket és összefoglaló munkát, így Somogy megye faunakatalógusát (szerk. ÁBRAHÁm 2001), valamint újabb közleményeket néztünk át részletesen. A madarak esetén a MME Nomenclator Bizottság (2008) által javasolt nevezéktant, emlösök esetén BIHARI et al. (2007) nevezéktanát alkalmaztuk.

\section{Eredmények}

A Kaposvári Egyetem Kaposvár-Toponár határában elterülő kampuszának parkjában összesen 320 állatfaj jelenlétét mutattuk ki.

\section{Invertebrata - gerinctelenek}

\section{Gastropoda - Csigák}

Arion lusitanicus (Mabille, 1868) spanyol lantoscsiga I; Xerolenta obvia (Menke, 1828) lapos kórócsiga; Helix pomatia (Linnaeus, 1758) éti csiga, V.

\section{Diplopoda - Ikerszelvényesek}

Glomeris pustulata (Fabricius, 1781); Megaphyllum unilineatum (Koch, 1838) egyvonalas vaspondró; Polydesmus collaris (Koch, 1847) sárganyakú ikerszelvényes.

\section{Arachnida - Pókszabásúak}

Araneus quadratus (Clerck, 1758) négyes keresztespók; Misumena vatia (Clerck, 1757) viráglakó karolópók; Pisaura mirabilis (Clerck, 1757) csodáspók; Salticus scenicus (Clerck, 1757) színészpók; Thomisus onustus (Walckenaer, 1805) fehér karolópók. 


\section{Insecta - Rovarok}

Aeshna mixta (Latreille, 1805) nádi acsa; Orthetrum cancellatum (Linnaeus, 1758) vízipásztor; Forficula auricularia (Linnaeus, 1758) közönséges fülbemászó; Mantis religiosa (Linnaeus, 1758) imádkozó sáska, V; Ephippigera ephippiger (Fiebig, 1784) nyerges szöcske; Phaneroptera nana (Fieber, 1853) pontozott repülöszöcske; Pholidoptera griseoaptera (De Geer, 1773) szürke avarszöcske; Tettigonia viridissima (Linnaeus, 1758) zöld lombszöcske; Gryllotalpa gryllotalpa (Linnaeus, 1758) lótetű; Gryllus campestris (Linnaeus, 1758) mezei tücsök; Aiolopus thalassinus (Fabricius, 1781) tengerzöld sáska; Calliptamus italicus (Linnaeus, 1758) olaszsáska; Chorthippus albomarginatus (De Geer, 1773) csinos rétisáska; Chorthippus biguttulus (Linnaeus, 1758) zengő tarlósáska; Chorthippus brunneus (Thunberg, 1815) közönséges tarlósáska; Chorthippus parallelus (Zetterstedt, 1821) közönséges rétisáska; Glyptobothrus (Chorthippus) mollis (Charpentier, 1825) halk tarlósáska; Gomphocerippus rufus (Linnaeus, 1758) erdei bunkóscsápúsáska; Odontopodisma schmidtii (Fieber, 1853) Schmidthegyisáska; Pezotettix giornae (Rossi, 1794) kis hegyisáska; Stenobothrus crassipes (Charpentier, 1825) szárnyatlan rétisáska; Stenobothrus stigmaticus (Rambur, 1838) kis rétisáska; Tetrix subulata (Linnaeus, 1761) közönséges töviseshátúsáska; Alydus calcaratus (Linnaeus, 1758) szőrös karimáspoloska; Coreus marginatus (Linnaeus, 1758) közönséges karimáspoloska; Eurygaster maura (Linnaeus, 1758) szerecsenpoloska; Graphosoma lineatum (Linnaeus, 1758) csíkos pajzspoloska; Henestaris halophilus (Burmeister, 1835) nyelesszemü bodobács; Leptopterna dolabrata (Linnaeus, 1758) közönséges mezeipoloska; Lygaeus equestris (Linnaeus, 1758) lovagbodobács; Lygaeus saxatilis (Scopoli, 1763) virágbodobács; Notonecta glauca (Linnaeus, 1758) hátonúszó poloska; Palomena prasina (Linnaeus, 1761) zöld bogyómászó; Pentatoma rufipes (Linnaeus, 1758) vöröslábú címerespoloska; Pyrrhocoris apterus (Linnaeus, 1758) verököltő bodobács; Raphigaster nebulosa (Poda, 1761) bencepoloska; Rhynocoris iracundus (Poda, 1761) gyilkospoloska; Tritomegas bicolor (Linnaeus, 1758) foltos földipoloska; Centrotus cornutus (Linnaeus, 1758) szarvas kabóca; Cercopis sanguinolenta (Scopoli, 1763) vérpettyes kabóca; Idiocerus heydenii (Kirschbaum, 1868); Philaenus spumarius (Linnaeus, 1758) változó tajtékoskabóca; Xanthodelphax flaveolus (Flor, 1861); Phryganea grandis (Linnaeus, 1758) nagy pozdorján; Panorpa communis (Linnaeus, 1758) közönséges skorpiólégy; Chrysopa carnea (Stephens,1863) közönséges fátyolka; Chrysopa perla (Linnaeus, 1758) aranyszemü fátyolka; Aedes cantans (Meigen, 1818) erdei szúnyog; Bibio marci (Linnaeus, 1758) tavaszi bársonylégy; Culex pipiens (Linnaeus, 1758) dalos szúnyog; Nephrotoma macula (Linnaeus, 1977) foltos tarkatipoly; Tipula oleracea (Linnaeus, 1758) közönséges lószúnyog; Calliphora vicina (Robineau-Desvoidy, 1830) kék dongólégy; Chrysotoxum cautum (Harris, 1776) hosszúcsápú zengőlégy; Drosophila melanogaster
(Fabricius, 1787) közönséges muslica; Epistrophe balteata (De Geer, 1776) ékfoltos zengőlégy; Eristalis tenax (Linnaeus, 1758) közönséges herelégy; Lucilia caesar (Linnaeus, 1758) fémzöld döglégy; Lucilia sericata (Meigen, 1826) selymes döglégy; Musca domestica (Linnaeus, 1758) házi légy; Sarcophaga carnaria (Linnaeus, 1758) közönséges húslégy; Stomoxys calcitrans (Linnaeus, 1758) szuronyos istállólégy; Tabanus bovinus (Linnaeus, 1758) marhabögöly; Apis mellifera (Linnaeus, 1758) mézelő méh; Bombus lapidarius (Linnaeus, 1758) kövi poszméh; Bombus terrestris (Linnaeus, 1758) földi poszméh; Camponotus vagus (Scopoli, 1763) fekete lóhangya; Formica rufa (Linnaeus, 1761) erdei vöröshangya, V; Polistes dominulus (Christ, 1791) déli papírdarázs; Polistes gallicus (Linnaeus, 1761) francia darázs; Tetramorium caespitum (Linnaeus, 1758) gyepi hangya; Vespa crabro crabro (Linnaeus, 1758) lódarázs; Vespula germanica (Fabricius, 1775) német darázs; Anoplius viaticus viaticus (Linnaeus, 1758) közönséges útonálló-darázs; Philanthus triangulum (Fahringer, 1922) méhfarkas; Sceliphron destillatorium (Illiger, 1807) közönséges lopódarázs; Systropha curvicornis (Scopoli, 1770) törtcsápú méh; Tremex fuscicornis (Fabricius, 1787) sárgagyűrűs fadarázs; Heodes tityrus (Poda, 1761) barna tüzlepke; Lycaena dispar (Werneburg, 1864) nagy tüzlepke, V; Lycaena phlaeas (Linnaeus, 1761) közönséges tüzlepke; Lysandra (Polyommatus) bellargus (Rottemburg, 1775) égszínü boglárka; Polyommatus icarus (Rottemburg, 1775) közönséges boglárka; Carcharodus alceae (Esper, 1780) mályva-busalepke; Ochlodes sylvanus (Esper, 1777) erdei busalepke; Syntomis phegea (Linnaeus, 1758) fehérpettyes álcsüngő; Maniola jurtina (Linnaeus, 1758) nagy ökörszemlepke; Melanargia galathea (Linnaeus, 1758) sakktáblalepke; Pararge aegeria (Linnaeus, 1758)erdei szemeslepke; Vanessa cardui (Linnaeus, 1758) bogáncslepke; Inachis io (Linnaeus,1758) nappali szemeslepke, V; Vanessa atalanta (Linnaeus, 1758) admirálislepke, V; Amara aenea (Degeer, 1774) érces közfutó; Amara familiaris (Duftschmidt, 1812); Harpalus affinis (Schranck, 1781) közönséges fémfutó; Pterostichus vulgaris (Linnaeus, 1758) közönséges gyászfutó; Zabrus spinipes (Schellenberg, 1806); Zabrus tenebroides (Goeze, 1777) gabonafutrinka; Brachynus crepitans (Linnaeus, 1758) nagy pöfögőfutrinka; Calosoma inquisitor (Linnaeus, 1759) kis bábrabló, V; Carabus cancellatus (Illiger, 1798) ragyás futrinka, V; Carabus coriaceus (Linnaeus, 1758) bőrfutrinka, V; Carabus germarii (Sturm, 1815) dunántúli kékfutrinka, V; Carabus ulrichii (Germar, 1824) rezes futrinka, V; Carabus marginalis (Fabricius, 1794) szegélyes futrinka, V; Rhantus adspersus (Panzer, 1797); Amphimallon solstitialis (Linnaeus, 1758) sárga cserebogár; Anisoplia austriaca (Herbst, 1783) osztrák szipoly; Cetonia aurata (Linnaeus, 1761) aranyos rózsabogár; Copris lunaris (Linnaeus, 1758) holdszarvúbogár, V; Dorcus paralellepipedus (Linnaeus, 1758) kis szarvasbogár, V; Geotrupes spiniger (Marsham, 1802) közönséges ganéjtúró; Geotrupes stercorosus (Hartmann, 1791) erdei ganéjtú- 
ró; Geotrupes vernalis (Linnaeus, 1758) tavaszi ganéjtúró; Lucanus cervus (Linnaeus, 1758) szarvasbogár, V; Melolontha melolontha (Linnaeus, 1758) májusi cserebogár; Oryctes nasicornis (Linnaeus, 1758) orrszarvú bogár, V; Oxythyrea funesta (Poda, 1761) sokpettyes virágbogár; Potosia cuprea (Herbst, 1786) rezes rózsabogár; Tropinota (Epicometis) hirta (Poda, 1761) bundásbogár; Coccinella bipunctata (Linnaeus, 1758) kétpettyes katicabogár; Coccinella septempunctata (Linnaeus, 1758) hétpettyes katicabogár; Harmonia axyridis (Pallas, 1773) harlekin katica, I; Subcoccinella vigintiquatuorpunctata (Linnaeus, 1758) lucernaböde; Synharmonia conglobata (Ganglbauer, 1899) rózsás katica; Thea vigintiduopunctata (Linnaeus, 1758) huszonkétpettyes katica; Chrysolina sanguinolenta (Linnaeus, 1758); Clytra laeviuscula (Ratzeburg, 1837) füzfa-zsákhordóbogár; Cryptocephalus sericeus (Weise, 1882) nagy fészkesbogár; Diabrotica virgifera virgifera (Leconte, 1868) amerikai kukoricabogár; Lachnaia sexpunctata (Scopoli, 1763) szörösnyakú zsákhordóbogár; Oulema melanopa (Linnaeus, 1758) vörösnyakú árpabogár; Phytodecta fornicata (Brueggemann, 1873) lucernabogár; Smaragdina affinis (Illiger, 1794) tölgy-levélbogár; Malachius bipustulatus (Linnaeus, 1758) kétfoltos bibircsbogár; Cantharis fusca (Linnaeus, 1758) közönséges lágybogár; Cantharis nigricans (Müller, 1776) feketéllő lágybogár; Cantharis rustica (Fallen, 1807) suszterbogár; Rhagonycha fulva (Scopoli, 1763) feketevégü lágybogár; Calamobius filum (Rossi, 1790) hosszúcsápú szalmacincér, V; Dorcadion aethiops (Scopoli ,1763) fekete gyalogcincér; Echinocerus (Plagionotus) floralis (Pallas, 1773); Leptura aethiops (Poda, 1761); Neoclytus acuminatus (Fabricius, 1775) amerikai darázscincér, l; Meloe proscarabeus (Linnaeus, 1758) közönséges nünüke; Meloe violaceus (Marsham, 1802) kék nünüke; Ocypus olens (Müller, 1764) bűzös holyva; Othius punctulatus (Goeze, 1777) nagy avarholyva; Oxyporus rufus (Linnaeus, 1758); Staphylinus caesareus (Cederhjelm, 1798) aranysújtásos holyva; Blaps lethifera (Marsham, 1802) közönséges büzbogár; Gnaptor spinimanus (Pallas, 1781) pohos gyászbogár; Necrophorus vespillo (Linnaeus, 1758) közönséges temetőbogár; Silpha tristis (Illiger, 1798) szemecskés dögbogár; Ipidia quadrimaculata (Quensel, 1790) bordás fénybogár; Crypticus quisquilius (Linnaeus, 1761) fürge szemétbogár; Opatrum sabulosum (Linnaeus, 1761) sárbogár; Agrypnus murinus (Linnaeus, 1758) egérszínű pattanó; Anostirus purpureus (Poda, 1761) tűzvörös pattanó; Hister quadrimaculatus (Linnaeus, 1758) közönséges sutabogár; Anthrenus olgae (Schaeffer, 1766) kis múzeumbogár; Bagous glabrirostris (Herbst, 1797); Cleonus piger (Scopoli, 1763) bogáncsbarkó; Cleonus punctiventris (Schoenherr, 1826) lisztes répabarkó; Rhynocyllus conicus (Frölich, 1792) fogfájásmulasztó ormányos; Tanymecus palliatus (Germar, 1817) hegyesfarkú barkó.

Rövidítések: I = inváziós faj, V = védett faj.

\section{Vertebrata - Gerincesek}

\section{Amphibia - Kétéltüek}

Pelophylax ridibundus $\times$ Pelophylax lessonae kecskebéka fajkomplex, V; Rana dalmatina (Bonaparte, 1840) erdei béka, V; Bufo bufo (Linnaeus, 1758) barna varangy, V; Bufo viridis (Laurenti, 1768) zöld varangy, V.

Rövidítések: $V$ = védett faj.

\section{Reptilia - Hüllök}

Lacerta agilis (Linnaeus, 1758) fürge gyík, V; Lacerta viridis (Laurenti, 1768) zöld gyík, V; Anguis fragilis fragilis (Linnaeus, 1758) lábatlan gyík, V; Natrix tessellata (Laurenti, 1768) kockás sikló, V; Natrix natrix (Linnaeus, 1758) vízi sikló, V.

Rövidítések: $V$ = védett faj.

\section{Aves - Madarak}

Cygnus olor (Gmelin, 1789) bütykös hattyú, Átr; Anser fabalis (Latham, 1787) vetési lúd, Átr; Anser albifrons (Scopoli, 1769) nagy lilik, Átr; Anser anser (Linnaeus, 1758) nyári lúd, Átr; Anas platyrhynchos (Linnaeus, 1758) tőkés réce, Tápl; Coturnix coturnix (Linnaeus, 1758) fürj, Fész, V; Phasianus colchicus (Linnaeus, 1758) fácán, Fész; Nycticorax nycticorax (Linnaeus, 1758) bakcsó, Átr, FV; Egretta garzetta (Linnaeus, 1766) kis kócsag, Átr, FV; Egretta alba (Linnaeus, 1758) nagy kócsag, Tápl, FV; Ardea cinerea (Linnaeus, 1758) szürke gém, Tápl, V; Ardea purpurea (Linnaeus, 1766) vörös gém, Átr, FV; Ciconia ciconia (Linnaeus, 1758) fehér gólya, Tápl, FV; Circus aeruginosus (Linnaeus, 1758) barna rétihéja, Tápl, V; Circus cyaneus (Linnaeus, 1766) kékes rétihéja, Von, V; Accipiter gentilis (Linnaeus, 1758) héja, Tápl, V; Accipiter nisus (Linnaeus, 1758) karvaly, Tápl, V; Buteo buteo (Linnaeus, 1758) egerészölyv, Tápl, V; Falco tinnunculus (Linnaeus, 1758) vörös vércse, Tápl, V; Falco subbuteo (Linnaeus, 1758) kabasólyom, Átr, V; Falco peregrinus (Tunstall, 1771) vándorsólyom, Tápl, FV; Grus grus (Linnaeus, 1758) daru, Átr, V; Vanellus vanellus (Linnaeus, 1758) bíbic, Tápl, V; Columba livia forma domestica (Gmelin, 1789) parlagi galamb, Fész; Columba palumbus (Linnaeus, 1758) örvös galamb, Fész; Streptopelia decaocto (Frivaldszky, 1838) balkáni gerle, Fész; Streptopelia turtur (Linnaeus, 1758) vadgerle, Fész, V; Cuculus canorus (Linnaeus, 1758) kakukk, Tápl, V; Tyto alba (Scopoli, 1769) gyöngybagoly, Tápl, FV; Athene noctua (Scopoli, 1769) kuvik, Fész, FV; Strix aluco (Linnaeus, 1758) macskabagoly, Fész, V; Asio otus (Linnaeus, 1758) erdei fülesbagoly, Von, V; Apus apus (Linnaeus, 1758) sarlósfecske, Tápl, V; Merops apiaster (Linnaeus, 1758) gyurgyalag, Fész, FV; Jynx torquilla (Linnaeus, 1758) nyaktekercs, Fész, V; Picus viridis (Linnaeus, 1758) zöld küllö, Tápl, V; Dryocopus martius (Linnaeus, 1758) fekete harkály, Tápl, V; Dendrocopos major (Linnaeus, 1758) nagy fakopáncs, Fész, V; Dendrocopos medius (Linnaeus, 1758) közép fakopáncs, Fész, V; Dendrocopos minor (Linnaeus, 1758) kis fakopáncs, Fész, V; Galerida cristata (Linnaeus, 1758) búbospacsirta, Fész, V; 
Alauda arvensis (Linnaeus, 1758) mezei pacsirta, Fész, V; Riparia riparia (Linnaeus, 1758) partifecske, Tápl, V; Hirundo rustica (Linnaeus, 1758) füsti fecske, Fész, V; Delichon urbicum (Linnaeus, 1758) molnárfecske, Fész, V; Anthus pratensis (Linnaeus, 1758) réti pityer, Von, V; Motacilla flava (Linnaeus, 1758) sárga billegető, Tápl, V; Motacilla alba (Linnaeus, 1758) barázdabillegető, Fész, V; Bombycilla garrulus (Linnaeus, 1758) csonttollú, Tápl, V; Troglodytes troglodytes (Linnaeus, 1758) ökörszem, Fész, V; Erithacus rubecula (Linnaeus, 1758) vörösbegy, Fész, V; Luscinia megarhynchos (C. L. Brehm, 1831) fülemüle, Fész, V; Phoenicurus ochruros (S. G. Gmelin, 1774) házi rozsdafarkú, Fész, V; Saxicola rubicola (Linnaeus, 1766) cigánycsuk, Fész, V; Oenanthe oenanthe (Linnaeus, 1758) hantmadár, Tápl, V; Turdus merula (Linnaeus, 1758) fekete rigó, Fész, V; Turdus pilaris (Linnaeus, 1758) fenyőrigó, Von, V; Turdus philomelos (C. L. Brehm, 1831) énekes rigó, Fész, V; Turdus viscivorus (Linnaeus, 1758) léprigó, Fész, V; Sylvia curruca (Linnaeus, 1758) kis poszáta, Fész, V; Sylvia atricapilla (Linnaeus, 1758) barátposzáta, Fész, V; Phylloscopus sibilatrix (Bechstein, 1793) sisegő füzike, Tápl, V; Phylloscopus collybita (Vieillot, 1817) csilpcsalpfüzike, Fész, V; Phylloscopus trochilus (Linnaeus, 1758) fitiszfüzike, Fész, V; Regulus regulus (Linnaeus, 1758) sárgafejü királyka, Tápl, V; Regulus ignicapilla (Temminck, 1820) tüzesfejü királyka, Tápl, V; Muscicapa striata (Pallas, 1764) szürke légykapó, Fész, V; Aegithalos caudatus (Linnaeus, 1758) őszapó, Fész, V; Parus palustris (Linnaeus, 1758) barátcinege, Fész, V; Parus cristatus (Linnaeus, 1758) búbos cinege, Von, V; Parus ater (Linnaeus, 1758) fenyvescinege, Von, V; Parus caeruleus (Linnaeus, 1758) kék cinege, Fész, V; Parus major (Linnaeus, 1758) széncinege, Fész, V; Sitta europaea (Linnaeus, 1758) csuszka, Fész, V; Certhia brachydactyla (C. L. Brehm, 1820) rövidkarmú fakusz, Fész, V; Oriolus oriolus (Linnaeus, 1758) sárgarigó, Fész, V; Lanius collurio (Linnaeus, 1758) tövisszúró gébics, Fész, V; Lanius excubitor (Linnaeus, 1758) nagy örgébics, Von, V; Garrulus glandarius (Linnaeus, 1758) szajkó, Fész; Pica pica (Linnaeus, 1758) szarka, Fész; Corvus monedula (Linnaeus, 1758) csóka, Tápl, V; Corvus frugilegus (Linnaeus, 1758) vetési varjú, Tápl, V; Corvus corone cornix (Linnaeus, 1758) dolmányos varjú, Fész; Corvus corax (Linnaeus, 1758) holló, Tápl, V; Sturnus vulgaris (Linnaeus, 1758) seregély, Fész; Passer domesticus (Linnaeus, 1758) házi veréb, Fész, V; Passer montanus (Linnaeus, 1758) mezei veréb, Fész, V; Fringilla coelebs (Linnaeus, 1758) erdei pinty, Fész, V; Fringilla montifringilla (Linnaeus, 1758) fenyőpinty, Von, V; Serinus serinus (Linnaeus, 1766) csicsörke, Fész, V; Carduelis chloris (Linnaeus, 1758) zöldike, Fész, V; Carduelis carduelis (Linnaeus, 1758) tengelic, Fész, V; Carduelis spinus (Linnaeus, 1758) csíz, Von, V; Carduelis cannabina (Linnaeus, 1758) kenderike, Fész, V; Loxia curvirostra (Linnaeus, 1758) keresztcsőrü, Tápl, V; Pyrrhula pyrrhula (Linnaeus, 1758) süvöltö, Von, V; Coccothraustes coccothraustes
(Linnaeus, 1758) meggyvágó, Tápl, V; Emberiza citrinella (Linnaeus, 1758) citromsármány, Fész, V; Emberiza schoeniclus (Linnaeus, 1758) nádi sármány, Von, V; Emberiza calandra (Linnaeus, 1758) sordély, Fész, V.

Rövidítések: Von = vonuló (és/vagy téli vendég), Tápl = táplálkozó, Fész = fészkelő, Átr = átrepülő; $V=$ védett faj, $F V=$ fokozottan védett faj.

\section{Mammalia - Emlősök}

Erinaceus roumanicus (Barrett-Hamilton, 1900) keleti sün, Megf, V; Crocidura leucodon (Hermann, 1780) mezei cickány, Kuv, V; Crocidura suaveolens (Pallas, 1811) keleti cickány, PJ, V; Sorex araneus (Linnaeus, 1758) erdei cickány, Kuv, V; Sorex minutus (Linnaeus, 1766) törpe cickány, PJ, V; Neomys anomalus (Cabrera, 1907) Miller-vízicickány, PJ, V; Neomys fodiens (Pennant, 1771) közönséges vízicickány, PJ, V; Talpa europaea (Linnaeus, 1758) közönséges vakond, Megf, V; Nyctalus noctula (Schreber, 1774) rőt koraidenevér, Megf, V; Pipistrellus kuhlii (Kuhl, 1819) fehérszélü törpedenevér, Megf, V; Eptesicus serotinus (Schreber, 1774) közönséges késeidenevér, Megf, V; Lepus europaeus (Pallas, 1788) mezei nyúl, Kuv; Sciurus vulgaris (Linnaeus, 1758) vörös mókus, Megf, V; Muscardinus avellanarius (Linnaeus, 1758) mogyorós pele, Kuv, V; Glis glis (Linnaeus, 1766) nagy pele, Megf, V; Microtus agrestis (Linnaeus, 1761) csalitjáró pocok, Kuv, V; Microtus arvalis (Pallas, 1788) mezei pocok, Kuv; Microtus subterraneus (de Selys-Longchamps, 1836) közönséges földipocok, Kuv; Arvicola amphibius (korábban: Arvicola terrestris) (Linnaeus, 1758) közönséges kószapocok, Kuv; Myodes glareolus (korábban: Clethrionomys glareolus) (Schreber, 1780) vöröshátú erdeipocok, Csapd; Apodemus agrarius (Pallas, 1771) pirók erdeiegér, Kuv; Apodemus flavicollis (Melchior, 1834) sárganyakú erdeiegér, Kuv, Csapd; Apodemus sylvaticus (Linnaeus, 1758) közönséges erdeiegér, Csapd; Micromys minutus (Pallas, 1771) törpeegér, Kuv, V; Mus musculus (Linnaeus, 1758) házi egér, Kuv, Csapd; Rattus norvegicus (Berkenhout, 1769) vándorpatkány, Megf; Felis sylvestris f. catus (Linnaeus, 1758) házi macska, Megf; Vulpes vulpes (Linnaeus, 1758) vörös róka, Megf; Mustela erminea (Linnaeus, 1758) hermelin, Megf, V; Mustela nivalis (Linnaeus, 1766) menyét, Megf, V; Mustela putorius (Linnaeus, 1758) közönséges görény Csapd; Martes foina (Erxleben, 1777) nyest, Megf, Csapd; Meles meles (Linnaeus, 1758) borz, Megf; Sus scrofa (Linnaeus, 1758) vaddisznó, Megf.

Rövidítések: PJ = PURGER Jenő (2005) mutatta ki Toponáron végzett gyöngybagolyköpet vizsgálatokból, Megf = megfigyelés, Kuv = kuvik köpet vizsgálatból, Csapd = csapda; $V$ = védett faj. 


\section{Következtetések}

A területen összesen 177 gerinctelen faj jelenlétét mutattuk ki, melyből 19 volt védett és 3 inváziós faj. Közülük kiemeljük a ritka és impozáns szegélyes futrinkát (Carabus marginalis), melynek hazánkból nagyrészt csak Somogyból vannak adatai (HoRvatovicH 1981, 1990, Merkl és Vig 2011). A Glomeris pustulata fajt korábban csak a Bakonyból és a Börzsönyböl írták le (JeRmy 1942, Korsós 1997). Az imádkozó sáska (Mantis religiosa) bár nem számít ritkaságnak, előfordulását főként a Zselicben és Belső-Somogyban említik (ÁBRAHÁM 1993). A veszélyeztetett fajként számon tartott törtcsápú méh (Systropha (Eucera) curvicornis) előfordulása a közelben a Boronka-mellékén (JózAN 1992) és a Dráva-mentén ismert (JózAn 1995). Az orrszarvú bogár (Oryctes nasicornis) is a ritkán kimutatott fajok közé tartozik.

Kétéltűek közül 4, hüllök közül 5 faj jelenlétét mutattuk ki. Somogy megyei elöfordulásaik ismertek (pl. MARIÁN 1957, MAJer 1992a, 1992b, Puky et al. 2005, ÁBRAHÁM 2009).

A madarak közül 100 fajt figyeltünk meg, melyből 9 volt fokozottan védett. Előfordultak közöttük Somogy megyében közönséges és ritkán leírt fajok egyaránt (FöldVÁRY 1929, FAlLon-Kund 1948, Nagy és Pintér 1994, Purger és FenYösı 2001, Haraszthy 2014). A parkban 52 faj volt jelen fészkelőként. Érdekes lehet a hazánkban szórványosan előforduló tüzesfejü királyka (Regulus ignicapilla) megfigyelése, melynek Baranya megyéből költése is ismert. A madarak tekintetében gyakoriak a generalista fajok, pl. mezei veréb (Passer montanus), széncinege (Parus major), de olykor alkalmi „vendégként” vízimadarakat is megfigyeltünk, mint pl. a bakcsót (Nycticorax nycticorax), a nagy kócsagot (Egretta alba) vagy a vörös gémet (Ardea purpurea). Érdekes adat a daru (Grus grus) vagy a vándorsólyom (Falco peregrinus) megjelenése a park felett. A darvak a Dunántúlon ritkábban fordulnak elő, mint az Alföldön, de szórványosan láthatók kisebb csapatok (birding.hu adatok), a park felett köröző csapataikat többször is megfigyeltük. A vándorsólymok közül korábban kóborló egyedeket lehetett megfigyelni, de ma már az országban több helyen költ (HARASZTHY 2014).

Az emlősök közül a 35 megfigyelt fajból 17 volt védett, közülük egyik sem számít ritkaságnak Somogy megyében (LANSZKI és PuRger 2001, HeLtal et al. 2010, PuRger 2013). A parkban kedvencként tartott házi macska számos ok miatt a világszerte nyilvántartott száz legproblémásabb inváziós állatfaj közé tartozik (Lowe et al. 2000). A Kaposvár-Toponár területén (PuRger 2005) és a Kaposvári Egyetem parkjában gyűjtött bagolyköpetekre épülő vizsgálatok (LANSZKI 1999, 2006, 2008) viszonylag jól feltárták a térség kisemlős faunáját (Id. BIHARI et al. 2007). Újdonságok leginkább a denevérek közül várhatók.
Mivel a park az évek során folyamatos változásokon esik át, az esetleges jövőbeli átalakítások alkalmával a következő kis energiabefektetéssel és anyagi ráfordítással is megvalósítható élőhelyfejlesztési javaslatokkal élünk. Célszerü lenne a fasorok és járdák mentén további átmeneti, szegély-jellegű élőhelyek kialakítása, őshonos cserjék - különös tekintettel a madarak számára táplálékot is nyújtó bogyótermésüekre - nem csupán nagyobb tömbökben, hanem térben elszórtabban való ültetésével. A meglévő és később keletkező odvas fák kímélete (természetesen az esetleges balesetveszély elhárítása mellett), kedvezően hathatna odúlakú fajok megtelepedése és megmaradása szempontjából. Bokorcsoportok által rejtett zugokban a lehullott avar, vagy száraz ágak meghagyásával több avarhoz kötődő állatfajnak is kedvezhetnénk, pl. sünöknek telelöhely kereséskor, vagy a talajfelszínen táplálék után kutató madaraknak táplálékbázist jelenthetne az avar lebontását végző élővilág. Az egynyári dísznövényekből álló ágyásokban a lehető legváltozatosabb fajösszetétel biztosításával, minél színesebb, illatosabb, lehetőleg hazai növényfajok alkalmazásával szélesíthető lenne a bevonzható rovarok köre. Érdemes lenne feldolgozni a park környezetének történetét is, ugyanis az első katonai térképezés idején (1782-1785) készült térképen szereplő jelölés szerint itt, a Festetics család birtokán egy franciakert lehetett.

Összességében, a park számos faj élőhelyéül szolgál. Egyesek számára feltehetően a közelben található állattartó telepek nyújthattak kedvező feltételeket. Ilyen lehet például a védett közönséges holdszarvú-ganéjtúró (Copris lunaris), melynek lárvája patások trágyájában fejlődik. A mezőgazdasági kártevő rovarok a környező mezőgazdasági művelés alatt álló területekről érkezhettek. Vizes élőhelyekhez kötődő madár és emlősfajok jelenlétére a közelben található Deseda-tó és patakja adhat magyarázatot. A park változatos növényzete ugyanakkor önmagában is táplálékot, búvóhelyet, fészkelő, szaporodó helyet nyújt számos állatfaj számára. Az általunk listázott fajok többségét - köztük közönséges, mindennapi fajokat a vizsgált park körzetéből eddig nem írták le (v.ö. pl. ÁBRAHÁM szerk. 2001). További vizsgálatok bizonyára újabb fajok jelenlétét mutatják ki. Javasoljuk a meglevő adatbázis bővítését, különösen a hiányosan feltárt taxonok esetén a célzott vizsgálatok elvégzését.

\section{Köszönetnyilvánítás}

Köszönetünket fejezzük ki Dr. Pál-Fám Ferenc Tanár Úrnak a parkban található fák és cserjék határozásánál nyújtott segítségért. Köszönjük továbbá Nagyapáti Noéminek és Nagyapáti Györgynek az öszszefoglaló angol nyelvre való fordításában nyújtott segítségét. 


\section{Irodalom}

ÁBRAHÁM L. 1993: Védett állatok Somogyban (gerinctelenek). Múzeumi Tájékoztató 4: 29-35.

ÁBRAHÁm L. (szerk.) 2001: Somogy megye faunakatalógusa. Natura Somogyiensis, 1: 1-494.

ÁBRAHÁM L. (szerk.) 2009: Biodiverzitás Napok, Gyürüfü, 2006-2008. Natura Somogyiensis, 13: 1-209.

BIHARI Z., Csorba G. és Heltai M. (szerk.) 2007: Magyarország emlöseinek atlasza. Kossuth Kiadó, Budapest.

FALLON-Kund A. 1948: Madártani megfigyelések Somogyfajsz környékéröl. Nimród, 35: 94

FöLdVÁRY M. 1929: A Baláta-tó. Kócsag, 1: 10-12

HARASZTHY L. (szerk.) 2014: Natura 2000 fajok és élőhelyek Magyarországon. Pro Vértes Közalapítvány, Csákvár.

Heltal M., Lanszkı J., Szemethy L. és Tóth M. (szerk.) 2010: Emlős ragadozók Magyarországon. Mezőgazda Kiadó, Budapest.

Heltal M. és Szöcs E. 2008: Városi vadgazdálkodás. Jegyzet. Szent István Egyetem, Gödöllö.

HoRvatovich S. 1981: A Barcsi Borókás Tájvédelmi Körzet cicindelidái, carabidái és dytiscidái (Coleoptera). Dunántúli Dolgozatok Természettudományi Sorozat, 2: 65-79.

HoRvatovich S. 1990: A Zselic futóbogarai (Coleoptera: Carabidae). A Janus Pannonius Múzeum Évkönyve, 34: 5-14.

JERMY T. 1942: Rendszertani tanulmány a magyarországi Plesioceratákról (Diplopoda). Mathematika Természettudományi Közlemények, 39: 1-82.

JózAN Zs. 1992: A Boronka-melléki Tájvédelmi Körzet fullánkos hártyásszárnyú (Hymenoptera, Aculeata) faunájának alapvetése. Dunántúli Dolgozatok Természettudományi Sorozat, Pécs, 7: 163-210.

JózAn Zs. 1995: Adatok a tervezett Duna-Dráva Nemzeti Park fullánkos hártyásszárnyú (Hymenoptera, Aculeata) faunájának ismeretéhez. Dunántúli Dolgozatok Természettudományi Sorozat, Pécs, 8: 99-115

Korsós Z. 1997: Az ikerszelvényesek (Diplopoda) faunisztikai és taxonómiai kutatásának helyzete és irányai Magyarországon. Folia Historico Naturalia Musei Matraensis, 22: 85-98.

Korsós Z., Read, H. J., Barber, A. D., Gregory, S. J., Hornung, E., Jones, R. E., Kime, R. D., Lewis, J. G. E. \& Selden, P. A. 2006: Report on a collecting trip of the British Myriapod Group to Hungary in 1994. Bulletin of the British Myriapod \& Isopod Group, 21: $40-55$
LANSZKI J. 1999: Faunisztikai vizsgálat a Balaton-Dráva ökológiai hálózatban közvetett módszerekkel. Somogyi Műszaki Szemle, XXIII: 22-28.

LANSZKI J. 2006: A kuvik (Athene noctua) táplálék-összetétele egy Somogy megyei külvárosi élőhelyen. Natura Somogyiensis, Kaposvár, 9: 315-324.

LANSZKI J. 2008: Adalékok Dél-Dunántúli területek kisemlős faunájához bagolyköpetek alapján. Állattani Közlemények, 89: 23-30.

LANSZKI J. és PURGER J. J. 2001: Somogy megye emlösfaunája. Natura Somogyiensis, 1: 481-494.

Lowe, S., Browne, M., Boudjelas, S. \& De Poorter, M. 2000: 100 of the world's worst invasive alien species: a selection from the Global Invasive Species Database. SSC, IUCN, Gland.

MAJER J. 1992a: Baláta-tó zoológiai felmérése (különös tekintettel a madárfaunára). Somogy Megyei Múzeumok Közleményei, IX: 321-328.

MAJER J. 1992b: Boronka-melléki Tájvédelmi Körzet zoológiai felmérése (gerinces fauna) (1990-1991). Dunántúli Dolgozatok Természettudományi Sorozat, 7: 347-375

MARIÁN M. 1957: A Baláta gerinces állatvilága. Somogyi Almanach 1: 1-59.

MeRKL O. és VIG K. 2011: Bogarak a pannon régióban. Palatia Nyomda és Kiadó, Győr.

MME Nomenclator Bizottság 2008: Magyarország madarainak névjegyzéke. Nomenclator avium Hungariae. Magyar Madártani és Természetvédelmi Egyesület, Budapest.

NAGY I. 2008. Városökológia. Dialóg Campus Kiadó, Budapest-Pécs.

NAGY L. és PINTÉR A. 1994: Védett állatok Somogyban (gerincesek). Múzeumi Tájékoztató, Kaposvár, 1: 21-32.

PuKY M., SCHÁD P. és SzÖVÉNYI G. 2005: Magyarország herpetológiai atlasza. Varangy Akciócsoport Egesület, Budapest.

Purger J. J. 2005: Kaposvár és környékének (Somogy megye) kisemlős faunája, gyöngybagoly Tyto alba (Scopoli, 1769) köpetek vizsgálata alapján. Folia Historico Naturalia Musei Matraensis 29: 203-215

PuRger J. J. 2013: Kisemlösök faunisztikai felmérése Somogy megye északkeleti részén, gyöngybagoly Tyto alba (Scopoli, 1769) köpetek vizsgálata alapján. A Kaposvári Rippl-Rónai Múzeum Közleményei 1: 81-100.

Purger J. J. és FenYősı L. 2001: Somogy megye madárfaunája. Natura Somogyiensis, 1: 453-479. 